\title{
PENGARUH MATHEMATICS ANXIETY TERHADAP HASIL BELAJAR MATEMATIKA SISWA KELAS X SMK KARTIKA MAKASSAR
}

\author{
Nur Asrawati \\ STKIP YPUP Makassar, Makassar, Indonesia \\ nurasrawatiypup@gmail.com
}

\begin{abstract}
Abstrak
Penelitian ini bertujuan untuk mengetahui pengaruh negatif mathematics anxiety terhadap hasil belajar matematika siswa kelas X SMK Kartika Makassar. Penelitian ini adalah penelitian ex-post facto yang bersifat korelasional. Populasi dalam penelitian ini siswa kelas X SMK yang terdiri dari 10 kelas dengan jumlah 227 siswa. Sampel dalam penelitian ini adalah siswa kelas X RPL dengan jumlah 28 siswa. Data hasil penelitian dianalisis dengan menggunakan analisis deskriptif dan inferensial. Dari hasil analisis deskriptif menunjukan bahwa mathematics anxiety siswa kelas X SMK Kartika Makassar dikategorikan sedang, dengan nilai rata-rata 66,7 dan standar deviasi 8,62. Hasil belajar matematika siswa kelas X SMK Kartika Makassar dikategorikan sedang, dengan nilai rata-rata 70,2 dan standar deviasi 10,77. Hasil analisis inferensial menunjukan bahwa mathematics anxiety berpengaruh negatif terhadap hasil belajar matematika siswa kelas X SMK Kartika Makassar dengan kontribusi 23,4 \%. artinya $23,4 \%$ hasil belajar matematika siswa ditentukan oleh mathematics anxiety dan sisanya 76,6\% ditentukan oleh variabel lain yang tidak dijelaskan pada penelitian ini.
\end{abstract}

Kata Kunci: Mathematics anxiety, Hasil belajar matematika

\section{Pendahuluan}

Pesatnya perkembangan ilmu pengetahuan dan teknologi di Indonesia menuntut sumber daya manusia yang berkualitas. Pendidikan kemudian menjadi pioner utama dalam rangka penyiapan sumber daya manusia yang berkualitas. Proses untuk meningkatkan kualitas sumber daya manusia saat ini merupakan tanggung jawab seluruh masyarakat dan bangsa Indonesia adalah pendidikan. Standar proses pembelajaran dalam proses pendidikan menurut Permendikbud No. 22 Tahun 2016 adalah diselenggarakan secara interaktif, inspiratif, menyenangkan, menantang, memotivasi peserta didik untuk berpartisis aktif, serta memberika ruang yang cukup bagi prakarsa, minat, dan perkembangan fisik serta psikologis peserta didik dalam proses pembelajaran pendidik memberikan keteladanan. Salah satu tujuan dari proses pembelajaran adalah untuk meraih suatu hasil dalam belajar.

Pada UU No 20 Tahun 2003 Tentang Sistem Pendidikan Nasional Bab II pasal 3 tercantum sebagai berikut: pendidikan nasional bertujuan untuk mengembangkan hasil peserta didik agar menjadi manusia yang beriman dan bertakwa kepada Tuhan Yang Maha Esa, berakhlak mulia, sehat, berilmu, cakap, kreatif, mandiri dan menjadi warga negara yang demokratis serta bertanggung jawab. Rumusan tujuan di atas merupakan rujukan utama untuk 
penyelenggaraan pembelajaran bidang studi apa pun, antara lain dalam bidang studi matematika sekolah menengah (Hendriana dan Soemarmo, 2017).

Matematika memuat suatu kumpulan konsep dan operasi - operasi, tetapi di dalam pembelajaran matematika pemahaman siswa mengenai hal-hal tersebut lebih objektif dibanding mengembangkan kekuatannya dalam perhitungan-perhitungan. Guru yang baik akan menjelajahi daerah isi, mengeluarkan dan memperluas hubungan bidang studi, serta memperkenalkan kepada siswanya berhubungan dengan situasi konkret. Mereka mengajarkan pengetahuan dan keterampilan tersendiri. dalam penerapannya guru hanya mengajarkan konsep dan operasi matematika tanpa hal-hal di atas. Guru mengelompokan matematika sesuai dengan buku teks. Hal ini menyebabkan begitu luasnya konsep - konsep yang mesti dipelajari oleh siswa.

Guru seharusnya tidak hanya mengurus dan memberi tugas - tugas saja kepada siswa, tetapi harus menginternalisasikan tugas - tugas tersebut pada kebiasaan siswa dalam belajar dan keterbukaan dalam proses pembelajaran, siswa mempunyai ketetapan kapasitas untuk mengikat tipe - tipe item dan transformasi. Pendidikan matematika dalam tujuan pembelajarannya harus praktis dengan tidak mengabaikan keharusan pemahaman konsep yang merupakan pola struktur matematika. Proses pembelajaran matematika tampak masuk akal dengan struktur yang sederhana.

Salah satu mata pelajaran yang menjadi standar kelulusan dalam setiap jenjang pendidikan adalah pelajaran matematika. oleh karena itu pelajaran matematika bisa dikatakan sebagai pelajaran yang sangat penting dan berperan dalam upaya peningkatan mutu pendidikan indonesia. Namun, opini negatif tentang pelajaran matematika terlanjur berkembang dan melekat pada masyarakat khususnya siswa. Pelajaran matematika dianggap sebagai pelajaran yang sulit,karena karakteristik matematika yang bersifat abstrak.

Anggapan bahwa pelajaran matematika adalah pelajaran yang sulit dapat menimbulkan sikap yang berbeda - beda pada siswa. Sikap yang timbul biasa positif, seperti bersemangat dalam mempelajari dan mengikuti proses pembelajaran, karena merasa tertantang untuk menyelesaikan masalah - masalah matematika. namun, bisa juga timbul sikap yang negatif, seperti menjadi malas, merasa tertekan sehingga sulit untuk berkosentrasi, kurang percaya diri atau megalami gejala - gejala kecemasan seperti gugup, gelisah, panik, sakit kepala dalam proses pembelajaran matematika. kecemasan seperti itu dikenal dengan istilah kecemasan matematika (mathematics anxiety) Alfian Eka Utama, dkk (2018). Kecemasan matematika adalah salah satu faktor yang mempengaruhi hasil belajar matematika,faktor tersebut dapat dipengaruhi oleh beberapa hal, baik berkaitan dengan faktor internal maupun faktor eksternal 
peserta didik. Kecemasan matematika merupakan kondisi yang takut dan khawatir terhadap pembelajaran matematika, kecemasan matematika dapat muncul karena dipicu oleh kemampuan siswa yang kurang dalam matematika, model pembelajaran yang digunakan oleh guru, kesulitan matematika dan tidak percaya diri. Kecemasan terhadap matematika sering terjadi dikalangan siswa dan bahkan menjadi penentu persepsi mereka terhadap pelajaran matematika (Handayani, 2019).

Kecemasan matematika banyak terjadi di kalangan remaja dan bahkan menjadi penentu bagi pandangan mereka terhadap matematika kedepannya. kecemasan remaja dalam menghadapi matematika dikarenakan adanya beberapa faktor, yaitu faktor inteligensi, faktor di dalam diri remaja dan faktor lingkungan. Ellis (dalam Saputra, 2014) mengatakan bahwa kecemasan pada remaja disebabkan oleh adanya tingkat inteligensi yang berbeda pada diri remaja. Hal ini dijelaskan oleh Zeidner (dalam Saputra, 2014) kecemasan seseorang terhadap pelajaran matematika dikarenakan kurangnya ketertarikan siswa terhadap pelajaran matematika. kurangnya ketertarikan siswa terhadap pelajaran matematika disebabkan oleh inteligensi siswa dalam pelajaran matematika, siswa yang memiliki inteligensi tinggi akan cenderung lebih tertarik dan akan lebih eveluatif terhadap pelajaran matematika sedangkan siswa yang memiliki inteligensi rendah akan kurang tertarik dan kurang evaluatif terhadap pelajaran matematika Zeidner (dalam Saputra, 2014).

Menurut Spielberger (dalam slamento, 2010) membedakan kecemasan atas dua bagian; kecemasan sebagai suatu sifat (trait anxiety), yaitu kecenderungan pada diri seseorang untuk merasa terancam oleh sejumlah kondisi yang sebenarnya tidak berbahaya, dan kecemasan sebagai suatu keadaan (state anxiety), yaitu suatu keadaan atau kondisi emosional sementara pada diri seseorang yang ditandai dengan perasaan tegang dan kekhawatiran yang dihayati secara sadar serta bersifat subjektif, dan meningginya aktivitas sistem saraf otonom. Sebagai suatu keadaan, kecemasan biasanya berhubungan dengan situasi - situasi lingkungan yang khusus, misalnya situasi tes.

Berdasarkan beberapa hasil penlitian menyatakan bahwa kecemasan matematika merupkan salah satu faktor yang memilki hubungan negatif dengan hasil belajar. Vahedi dan Farrokhi (dalam Alfian eka utama,dkk, 2018) menemukan bahwa siswa yang memiliki tingkat kecemasan matematika yang tinggi memiliki hasil belajar matemtika yang rendah.

Berdasarkan pengalaman penulis yang pernah meneliti sebelumnya pada SMK Kartika diperoleh informasi bahwa hasil belajar siswa masih terbilang rendah hal tersebut dibuktikan ketika pada saat pelaksanaan pembelajaran matematika dimana siswa ketika diberikan permasalahan atau soal mengenai matematika masih banyak siswa yang sulit memahami 
rumus-rumus dan banyak siswa yang merasa gelisah atau kesulitan dalam menjawab atau menemukan solusi dari masalah matematika yang diberikan. Hal tersebut dapat menghambat pembelajaran di sekolah serta dapat juga menjadi penghambat dalam hasil belajar siswa pada mata pelajaran matematika. Sehingga berdasarkan permasalahan-permasalahan di atas, peneliti tertarik untuk melakukan penelitian tentang pengaruh mathematics anxiety terhadap hasil belajar matematika.

Berdasarkan latar belakang yang dikemukakkan diatas, dapat dirumuskan beberapa permasalahan sebagai berikut: (1) Seberapa besar tingkat mathematics anxiety siswa kelas X SMK Kartika makassar, (2) Seberapa besar hasil belajar matematika siswa kelas X SMK Kartika Makassar, (3) Apakah mathematics anxiety berpengaruh negatif terhaap hasil belajar matematika siswa kelas X SMK Kartika Makassar. Berdasarkan permasalahan ini maka tujuan penelitian ini adalah Untuk mengetahui tingkat mathematics anxiety siswa kelas X SMK Kartika Makassar, Untuk mengetahui hasil belajar matematika siswa kelas X SMK Kartika Makassar, dan Untuk mengetahui pengaruh negatif mathematics anxiety terhadap hasil belajar matematika siswa kelas X SMK Kartika Makassar

Penelitian ini diharapkan dapat bermanfaat bagi siswa, guru dan peneliti. Bagi siswa diharapkan dapat bermanfaat sebagai upaya peningkatan kualitas pembelajaran matematika siswa, bagi guru diharapkan dapayt mengetahui faktor-faktor yang mempengaruhi hasil belajar matemaytika siswa.

\section{Metode Penelitian}

Penelitian ini merupakan penelitian expost facto yang bersifat korelasional. Pada penelitian ini terdapat dua macam variabel yakni: mathematics anxiety $(\mathrm{X})$ adalah variabel bebas (independen) dan hasil belajar matematika siswa $(\mathrm{Y})$ adalah variabel terikat (dependen variabel).

Penelitian ini dilaksanakan di SMK Kartika makassar. Populasi dalam penelitian ini adalah seluruh siswa kelas X SMK Kartika Makassar. Teknik pengambilan sampel yang digunakan oleh peneliti adalah sampel dengan cara simple random sampling. Teknik random sampling merupakan tekink pengambilan sampel yang paling sederhana karena pengambilan anggota sampel dari populasi dilakukan secara acak tanpa memperhatikan strata yang ada dalam populasi. Cara pengambilan sampel dengan simple random sampling dapat dilakukan dengan metode undian. Data mathematics anxiety siswa terhadap hasil belajar matematika dianalisis menggunakan analisis regresi linear sederhana melalui SPSS versi 20 dan manual. Sebelumnya data tersebut diuji normalitasnya, linearitanya, dan hipotesisnya. 
Teknik Pengumpulan data dilakukan dengan mencatat peristiwa, karakteristik, atau nilai suatu variabel yang dapat dilakukan dalam berbagai setting, sumber, dan berbagai teknik/cara. Penelitian ini menggunakan instrumen berbentuk angket dan dokumentasi untuk menguji masing-masing variabel. Instrumen yang digunakan dalam pengumpulan data adalah Instrumen Tes hasil belajar dan instrumen Mathematics Anxienty (Kecemasan matematika).

Pada tahap analisis data yang didasarkan data sampel, dianalisis dengan menggunakan teknik analisis statistik deskriptif dan teknik analisis statistik inferensial.

\section{Hasil dan Pembahasan}

Dalam penelitian ini, tahap awal akan dilakukan analisis deskripsi. Analisis deskriptif tingkat mathematics anxiety dan hasil belajar matematika siswa Kelas X SMK Kartika Makassar dapat dilihat pada tabel berikut:

Tabel 1. Distribusi Skor Mathematics Anxiety

\begin{tabular}{clcc}
\hline Nilai & Kategori & frekuensi & Persentase (\%) \\
\hline $\mathrm{X} \leq 55$ & Sangat rendah & 1 & $3,57 \%$ \\
$55<\mathrm{X} \leq 63$ & Rendah & 4 & $14,29 \%$ \\
$63<\mathrm{X} \leq 71$ & Sedang & 14 & $50 \%$ \\
$71<\mathrm{X} \leq 79$ & Tinggi & 7 & $25 \%$ \\
$79<\mathrm{X}$ & Sangat tinggi & 2 & $7,14 \%$ \\
& Jumlah & 28 & $100 \%$ \\
\hline
\end{tabular}

Berdasarkan tabel 1 menunjukan bahwa nilai rata-rata mathematics anxiety (kecemasan matematika) siswa adalah 66,7 dari skor ideal 100. Hal ini menunjukkan bahwa tingkat mathematics anxiety (kecemasan matematika) siswa SMK Kartika Makassar berada pada kategori sedang. Pada tabel juga menunjukkan bahwa 1 siswa memiliki tingkat kecemasan matematika yang berada dalam kategori sangat rendah (3,57\% dari 28 siswa), sedangkan 4 siswa berada dalam kategori rendah (14,29\% dari 20 siswa), 14 siswa berada dalam kategori sedang (50\% dari 28 siswa), 7 siswa berada dalam kategori tinggi ( $25 \%$ dari 28 siswa), dan 2 siswa yang berada dalam kategori sangat tinggi (7,14 \% dari 20 siswa). Dengan nilai standar deviasi sebesar 8, 245 yang berarti bahwa penyebaran data tidak terlalau besar. Sedangkan nilai minimum dan maksimu yang diperoleh masing masing sebesar 55 dan 85 . 
Tabel 2. Distribusi Skor Hasil Belajar matematika siswa

\begin{tabular}{clcc}
\hline Nilai & Kategori & frekuensi & Persentase (\%) \\
\hline $\mathrm{X} \leq 53$ & Sangat rendah & 1 & $3,57 \%$ \\
$53<\mathrm{X} \leq 64$ & Rendah & 8 & $28,57 \%$ \\
$64<\mathrm{X} \leq 74$ & Sedang & 12 & $42,86 \%$ \\
$74<\mathrm{X} \leq 85$ & Tinggi & 6 & $21,43 \%$ \\
$85<\mathrm{X}$ & Sangat tinggi & 1 & $3,57 \%$ \\
& Jumlah & 28 & $100 \%$ \\
\hline
\end{tabular}

Pada tabel 2 menunjukkan bahwa rata-rata skor hasil belajar matematika siswa adalah 70,2 dari skor ideal 100. Hal ini menunjukkan bahwa hasil belajar matematika siswa kelas $\mathrm{X}$ SMK Kartika Makassar berada pada kategori sedang. Pada tabel juga menunjukkan bahwa tidak ada 1 orang siswa memiliki tingkat hasil belajar matematika yang berada dalam kategori sangat rendah (3,57 \% dari 28 siswa), sedangkan 8 siswa berada dalam kategori rendah $(28,57 \%$ dari 28 siswa), 12 siswa berada dalam kategori sedang (42,86\% dari 28 siswa), 6 siswa berada dalam kategori tinggi (21,43\% dari 28 siswa), dan 1 siswa yang berada dalam kategori sangat tinggi (3,57\% dari 28 siswa). Dengan nilai standar deviasi sebesar 10, 77 yang berarti bahwa penyebaran data tidak terlalau besar. Sedangkan nilai minimum dan maksimum yang diperoleh masing masing sebesar 55 dan 95.

Dalam analisis statistik inferensial, data penelotian akan dianalisis dengan menggunakan software SPSS (Statistical Package For Social Science) versi 20 dengan bantuan teknik transformasi data MSI (Method of Successive Interval) Berdasarkan pengujian normalitas yang bertujuan untuk mengetahui apakah data sampel yang digunakan dalam penelitian ini berdasar dari populasi yang berdistribusi normal atau tidak. Berdasarkan hasil uji normalitas dengan menggunakan teknik shapiro wilk, diperoleh nilai $\mathrm{W}_{\text {hit }}$ untuk kecemasan matematika siswa sebesar 0,950 lebih besar dari nilai $\mathrm{W}_{\text {tab }}$ sebesar 0,904 maka $\mathrm{H}_{0}$ diterima, sehingga dapat dinyatakan bahwa data dalam penelitian ini berasal dari populasi yang berdistribusi normal.

Selanjutnya pengujian normalitas untuk hasil belajar matematika siswa dalam penelitian ini berasal dari populasi yang berdistribusi normal atau tidak. Berdasarkan hasil uji normalitas dengan menggunakan teknik analisis shapiro wilk, diperoleh nilai $\mathrm{W}_{\text {hit }}$ untuk hasil belajar matematika siswa sebesar 0,956 lebih besar dari nilai $\mathrm{W}_{\text {tab }}$ sebesar 0,905 maka $\mathrm{H}_{0}$ diterima, sehingga dapat dinyatakan bahwa data dalam penelitian ini berasal dari populasi yang 
berdistribusi normal.

Uji linearitas dilakukan untuk mengetahui apakah variabel bebas dan variabel terikat mempunyai hubungan yang linear atau tidak. Berdasarkan hasil uji linearitas, diperoleh nilai $\mathrm{F}_{\text {hit }}$ sebesar 1,126 lebih kecil dari $\mathrm{F}_{\text {tab }}$ sebesar 4,67 maka $\mathrm{H}_{0}$ diterima. Kemudian untuk uji signifikan diperoleh nilai $F_{\text {hit }}$ sebesar 5,27 lebih besar dari nilai $\mathrm{F}_{\text {tab }}$ sebesar 4,43 maka $\mathrm{H}_{0}$ ditolak. Dengan demikian, dapat disimpulkan bahwa terdapat hubungan linear secara signifikan antaran variabel kecemasan matematika $(\mathrm{X})$ dengan variabel hasil belajar matematika siswa $(\mathrm{Y})$.

Berdasarkan uji-t, diperoleh bahwa nilai $t_{\text {hit }}$ sebesar $-2,294$ dan $t_{\text {tabel }}$ sebesar 1,734 sehingga $t_{\text {hit }}=-2,294<-t_{\text {tab }}=-1,734$ sedangkan berdasarkan hasil analisis SPSS diperoleh nilai signifikan sebesar 0.033 pada taraf $\alpha=0,05$ sehingga nilai sig $<\alpha$, maka $\mathrm{H}_{1}$ diterima. Dengan demikian dapat di simpulkan bahwa kecemasan matematika berpengaruh secara signifikan terhadap hasil belajar matematika siswa. Selanjutnya, diperoleh nilai R-square $\left(\mathrm{R}^{2}\right)$ sebesar 0,227 yang menunjukan bahwa $23,4 \%$ hasil belajar matematika siswa ditentukan atau dipengaruhi oleh kecemasan matematika dan sisanya 76,6\% ditentukan oleh variabel lain yang tidak dijelaskan dalam penelitian ini.

Berdasarkan teori Furner dan Berman (dalam Auliya, 2016) menggambarkan kecemasan matematika sebagai sindrom "saya tidak bisa", kecemasan matematika dapat disebabkan dari pengalaman matematika yang memalukan atau karena ketidakmampuan dalam menerapkan pemahaman dan penggunaan konsep matematis. Seperti yang terdapat pada hasil perolehan angket kecemasan matematika siswa kelas X SMK Kartika Makassar pada indikator kecemasan matematika yaitu kurang senang, dari dua butir pertanyaan yang bersifat negatif dan positif, pertanyaan yang bersifat negatif memiliki nilai lebih tinggi dari pertanyaan yang bersifat positif maka pada indikator ini dapat disimpulkan bahwa siswa kelas X SMK Kartika Makassar kurang senang dalam pembelajaran matematika.

Hal tersebut sejalan dengan beberapa hasil penelitian yang mengatakan bahwa kecemasan matematika merupakan salah satu faktor yang memiliki hubungan negatif dengan hasil belajar. Clute dan Hembree (dalam Auliya, 2016) menemukan bahwa peserta didik yang memiliki tingkat kecemasan yang tinggi memiliki hasil belajar matematika yang rendah. selanjutnya Hasil penelitian Daneshamooz, Alamolhodaei, dan Darvishian (dalam Auliya, 2016) juga menunjukan bahwa kecemasan matematika berkorelasi negatif dengan kinerja matematika.

Berdasarkan hasil penelitian dapat disimpulkan bahwa terdapat pengaruh negatif antara mathematics anxiety terhadap hasil belajar matematika siswa kelas X SMK Kartika makassar 
yang menandakan bahwa setiap peningkatan kecemasan matmatika yang dialami siswa maka akan menyebabkan menurunnya hasil belajar matematika siswa.

\section{Kesimpulan dan Saran}

Berdasarkan hasil penelitian dan pembahasan dapat disimpulkan:

a. Tingkat mathematics anxiety (kecemasan matematika) siswa kelas X SMK Kartika Makassar dikategorikan sedang dengan skor rata-rata sebesar 66,7

b. Hasil belajar matematika siswa kelas X SMK Kartika dikategorikan rendah dengan skor rata-rata sebesar 70,2 .

c. Mathematics anxiety (kecemasan matematika) berpengaruh negatif terhadap hasil belajar matematika siswa kelas X SMK Kartika Makassar

Berdasarkan hasil penelitian yang diperoleh, maka penulis dapat menyarankan kepada guru-guru agar lebih mengembangkan pembelajaran dengan berbagai macam metode atau model pembelajaran khususnya pembelajaran matematika sehingga menciptakan suasana belajar yang konduktif agar jangan sampai siswa memiliki kecemasan yang terlalu tinggi. Selain itu guru tetap memperhatikan faktor-faktor yang dapat mempengaruhi hasil belajar siswa baik dari faktor internal (psikologi siswa) maupun eksternal (lingkungan).

\section{DAFTAR PUSTAKA}

Auliya, Risma Nurul. 2016. Kecemasan Matematika dan Pemahaman Matematis. Jurnal Formatif 6(1): 12-22,2016.

Handayani, Shinta Dwi. 2019. Pengaruh Kecemasan Matematika Terhadap Pemahaman Konsep Matematika. SAP (susunan artikel pendidikan) Vol 4. No.1.

Hendriana, heris dan Soemarmo, Utari. 2017. Penilaian Pembelajaran MatematikaI. PT Refika Aditama: Bandung.

Lestari, Karunia Eko dan Yudhanegara, Mokhammad Ridwan. 2015. Penelitian Pendidikan Matematika. PT Refika Aditama: Bandung.

Nurani, Mawar. 2017. Pengaruh Motivasi Belajar dan Kecemasan Matematika Terhadap Kesadaran Metakognisi dan Kaitannya dengan Hasil Belajar Matematika Siswa Kelas VIII di SMP Negeri 3 Sungguminasa pada Materi Bangun Ruang Sisi Datar. online (Http://www.eprints.unm.ac.id. Pdf).

Priansa, Donni Juni. 2017. Pengembangan Strategi dan Model Pembelajaran. CV Pustaka Setia: Bandung.

Qausarina, Husnul. 2016. Pengaruh Kecemasan Matematika (Math Anxiaety) Terhadap Hasil 
Belajar Matematika Siswa Kelas X SMA Negeri 11 Banda Aceh. online

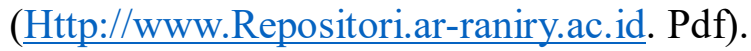

Sagala Syaiful. 2017. Konsep dan Makna Pembelajaran. Alfabeta: Bandung.

Saputra, Paulus Roy. 2014. Kecemasan Matematika dan Cara Menguranginya. Jurnal Pythagoras, Vol. 3(2): 75-84.

Satriyani. 2016. Pengaruh Kecemasan Matematika (Mathematics Anxiety) dan Gender Terhadap Kemampuan Pemecahan Masalah Matematis Siswa. online. (Http://www.uinjkt.ac.id. Pdf).

Slamento. 2013. Belajar dan Fakto-faktor yang Mempengaruhinya. PT Rineka Cipta: Jakarta.

Sugiyono. 2019. Statistik untuk Penelitian. Alfabeta: Bandung.

Suyono dan Hariyanto. 2017. Belajar dan Pembelajaran. PT Remaja Rosdakarya: Bandung.

Syah, Muhibbin. 2012. Psikologi Belajar. PT Raja Grafindo Persada: Jakarta.

Utama, Alfian Eka. 2018. Pengaruh Kecemasan Matematika (Mathematics Anxiety) Terhadap Hasil Belajar Matematika Siswa Kelas X SMK Negeri 8 Mataram Tahun Ajaran 2017/2018. online (Http://www.fkipunram.rf.gd. Pdf).

Wahab, Rohmalina. 2016. Psikologi Belajar. PT Raja Grafindo Persada: Jakarta.

Wahyudi dan Budiono, Inawati. 2011. Pemecahan Masalah Matematika. Widya Sani Press: salatiga. 